\title{
Deteksi Molekuler Entamoeba suis pada Babi di Rumah Potong Hewan Pegirian Surabaya
}

\author{
(MOLECULAR DETECTION OF ENTAMOEBA SUIS \\ IN PIGS AT PEGIRIAN SLAUGHTER HOUSE SURABAYA) \\ Fransiska Cicilia Beka ${ }^{1}$, Nunuk Dyah Retno Lastuti ${ }^{2}$, \\ Lucia Tri Suwanti ${ }^{2}$, Setiawan Koesdarto ${ }^{2}$, Mufasirin ${ }^{2}$, \\ Endang Suprihati ${ }^{2}$, Dyah Ayu Kurniawati ${ }^{1}$. \\ ${ }^{1}$ Mahasiswa Program Studi Magister Ilmu Penyakit \\ dan Kesehatan Masyarakat Veteriner, \\ ${ }^{2}$ Departemen Parasitologi Veteriner, \\ Fakultas Kedokteran Hewan, Universitas Airlangga \\ Kampus C Unair, Jalan Mulyorejo, \\ Kota Surabaya, Jawa Timur, Indonesia, 60115 \\ Telepon +6281226094872, 5993016; Fak. +62315993015 \\ Email: tswant@gmail.com
}

\begin{abstract}
This research aimed to detect E. suis in pigs slaughtered at Pegirian Slaughterhouse, Surabaya. A total of 63 pig stool samples were collected from Pegirian Slaughterhouse, Surabaya. Morphological detection of Entamoeba sp--. was done by floating methods (parasitological analysis). In addition, species determination of $E$. suis was conducted by PCR using primers Esuis764 (5'-ATC AAA TCA ATT AGG CAT AAC TA-3') and Esuis765 (5'-AAT TAA AAC CTT ACG GCT TTA AA-3') and the expected PCR product was $320 \mathrm{bp}$. DNA of the positive samples were extracted by DNAzol. The PCR was carried out in some positive samples selected randomly from the parasitological analysis. The results showed that $57.14 \%$ (36/63) of the samples were morphologically positive with Entamoeba sp. In term of species determination result, the molecular analysis relieved that the protozoan infecting swine at the Pegirian Slaughterhouse, Surabaya were E. suis.
\end{abstract}

Key words: slaughtered pigs, Entamoeba suis, Pegirian Slaughterhouse, Surabaya.

\begin{abstract}
ABSTRAK
Penelitian ini bertujuan untuk mendeteksi E. suis pada babi yang dipotong di Rumah Potong Hewan (RPH) Pegirian, Surabaya. Sebanyak 63 sampel feses babi dikoleksi dari RPH Pegirian Surabaya. Deteksi morfologis Entamoeba spp. dilakukan dengan metode apung (analisis parasitologi). Selain itu, penentuan spesies E. suis dilakukan dengan PCR menggunakan primer Esuis764 (5'-ATC AAA TCA ATT AGG CAT AAC TA-3') dan Esuis765 (5'-AAT TAA AAC CTT ACG GCT TTA AA-3') dan prodak PCR yang diharapkan adalah $320 \mathrm{bp}$. DNA dari sampel positif diekstraksi dengan DNAzol. PCR dilakukan pada beberapa sampel positif yang dipilih secara acak dari analisis parasitologi. Hasil penelitian menunjukkan 57,14\% (36/63) sampel secara morfologis positif Entamoeba sp. Hasil penentuan spesies berdasarkan analisis molekuler menemukan bahwa protozoa yang menginveksi babi di Rumah Potong Hewan Pegirian, Surabaya adalah E. suis.
\end{abstract}

Kata kunci: Babi, Entamoeba suis, Rumah Potong Hewan Pegirian Surabaya. 


\section{PENDAHULUAN}

Entamoeba adalah protozoa gastrointestinal yang ditemukan baik pada hewan vertebrata maupun invertebrata dan tersebar diseluruh dunia. Protozoa ini merupakan salah satu agen penyakit penting pada peternakan babi yang menyebabkan diare, terutama Entamoeba histolytica, E. polecki dan E. suis (Matsubayashi et al., 2014; Matsubayashi et al., 2015a, 2015b, 2016). Di antara protozoa tersebut, E. suis dilaporkan sebagai salah satu spesies Entamoeba yang paling sering menginfeksi babi. Selain diare, infeksi $E$. suis juga menyebabkan kolitis hemoragik sebagai akibat dari invasi pada lamina propria dan fagositosis sel darah (Matsubayashi et al., 2014).

Selama ini, penelitian Entamoeba spp. pada babi di Indonesia lebih banyak dilakukan berdasarkan uji parasitologis (morfologi) (Suryawan et al., 2014; Yuliari et al., 2013), tetapi identifikasi secara molekuler masih terbatas. Beberapa peneliti yang telah melaporkan penelitian molekuler Entamoeba di antaranya Wardhana et al., (2020) yang melaporkan prevalensi E. suis di Tangerang, Jawa Barat sebesar 81,1\%. Agustina et al., (2016) juga melaporkan prevalensi Entamoeba spp. secara molekuler pada babi di Bali adalah sebesar $84,7 \%$, tetapi studi ini belum menentukan spesiesnya.

Metode diagnostik yang umum dilakukan untuk mengidentifikasi Entamoeba adalah pemeriksaan mikroskopis pada feses berdasarkan karakter morfologisnya. Namun, metode tersebut memiliki kelemahan, yaitu tidak dapat membedakan spesies Entamoeba karena ukurannya yang sangat kecil dan hampir seragam (Verweij et al., 2003; Mohamadi dan Petri, 2006). Metode diagnostik modern yang dapat diterapkan untuk mengidentifikasi Entamoeba adalah metode molekuler yaitu, Polymerase Chain Reaction (PCR). Metode ini mudah dilakukan dan memiliki tingkat sensitifitas dan spesifitas yang tinggi sehingga tepat digunakan untuk mengidentifikasi Entamoeba hingga ke tingkat spesies (Sukprasert et al., 2008).

Rumah Potong Hewan (RPH) Pegirian Surabaya merupakan salah satu badan usaha milik daerah pemerintah Kota Surabaya. Rumah Potong Hewan menyediakan layanan penyembelihan hewan (sapi, kambing dan babi) dan menjadi wadah yang menyediakan kebutuhan daging bagi masyarakat. Total babi yang dipotong adalah sekitar 150 ekor per hari. Rumah Potong Hewan Pegirian surabaya menyediakan daging untuk didistribusikan ke pasar tradisional di Jawa Timur (Perwakot, 2010).

Penelitian ini bertujuan untuk mendeteksi E. suis dari feses babi di Rumah Potong Hewan (RPH) Pegirian Surabaya baik secara morfologis (mikroskopis) dan molekuler sehingga diperoleh gambaran sebaran amoebiasis pada babi yang dipotong pada RPH tersebut.

\section{METODE PENELITIAN}

\section{Sampel Penelitian}

Sebanyak 63 sampel feses babi dikumpulkan dalam waktu satu hari dari Rumah Potong Hewan (RPH) Pegirian Surabaya. Pengambilan sampel dilakukan pada saat pemisahan jeroan, setelah babi dipotong. Sampel feses diambil dari isi kolon babi kemudian disimpan dalam pot plastik yang berisi larutan kalium bikromat $2,5 \%$. Setiap pot plastik diberi label dan keterangan yang diperlukan. Sampel disimpan dalam ice box dan dibawa ke Departemen Parasitologi Veteriner, Fakultas Kedokteran Hewan, Universitas Airlangga, Surabaya untuk diperiksa.

\section{Pemeriksaan secara Parasitologis}

Tujuan pemeriksaan ini adalah untuk skrining pada sampel feses, sebelum dilakukan pemeriksaan secara molekular. Sampel feses diperiksa secara parasitologis menggunakan metode apung (Suwanti et al., 2011). Sampel dinyatakan positif apabila secara mikroskopis ditemukan bentuk kista atau tropozoit. Selanjutnya, semua sampel positif disimpan pada suhu $-20^{\circ} \mathrm{C}$ untuk analisis molekuler.

\section{Pemeriksaan Molekuler}

Pemeriksaan ini ditujukan untuk mengidentifikasi Entamoeba hingga ke aras spesies. Analisis molekuler hanya dilakukan pada enam sampel positif secara pemeriksaan parasitologis yang dipilih secara acak. Genom DNA Entamoeba diekstrak dari sampel-sampel positif secara molekuler $\left(\mathrm{DNAzol}^{\circledR}\right.$, Molecular Research Center, OH, USA) sesuai protokol pabrik. Uji molekular E. suis menggunakan primer spesifik, yaitu Esuis764 (5'-ATC AAA TCA ATT AGG CAT AAC TA-3') dan Esuis765 (5'-AAT TAA AAC CTT ACG GCT TTA AA-3') dengan target amplifikasi 320 bp (Clark et al., 
2006). Sebanyak $8,5 \mu \mathrm{L}$ destilated water dan 12,5 $\mu \mathrm{L}$ master mix dimasukkan ke dalam tabung PCR 0,2 $\mathrm{mL}$ Selanjutnya, kemudian ditambahkan $1 \mu \mathrm{L}$ primer Esuis764, $1 \mu \mathrm{L}$ primer Esuis765 dan $2 \mu \mathrm{L}$ DNA sampel. Kondisi thermocycler untuk mengamplifikasi fragment DNA $E$. suis adalah denaturasi awal $94^{\circ} \mathrm{C}$ selama lima menit, diikuti suhu $94^{\circ} \mathrm{C}$ selama 30 detik, annealing pada suhu $55^{\circ} \mathrm{C}$ selama 30 detik, extension pada suhu $72^{\circ} \mathrm{C}$ selama 30 detik, sebanyak 35 siklus dan diakhiri dengan extension akhir selama dua menit pada suhu $72^{\circ} \mathrm{C}$ (Verweij et al., 2001). Produk PCR kemudian divisualisasikan pada gel elektroforesis $1,5 \%$ yang dilihat di bawah sinar ultra violet/ UV. Sampel dinyatakan positif apabila terdapat pita DNA dengan ukuran 320 bp.

\section{HASIL DAN PEMBAHASAN}

Hasil pemeriksaan mikroskopis Entamoeba spp. pada sampel feses babi yang diambil dari RPH Pegirian Surabaya menunjukkan 57,14 \% (36/63) positif Entamoeba sp. Hasil ini lebih rendah dibandingkan dengan hasil penelitian Widisuputri et al., (2020) yang melaporkan prevalensi infeksi Entamoeba sp. pada babi di Bali yang mencapai hingga 99\%. Prevalensi amoebiasis yang tinggi juga dilaporkan oleh Kagira et al. (2010) yang menyatakan $87 \%$ pada babi di Kenya terinfeksi oleh E. suis. Namun demikian, hasil penelitian terbilang tinggi jika dibandingkan dengan laporan Damriyasa dan Bauer (2006) yang menemukan 15 dari 20 peternakan babi di Hesse Jerman yang terinfeksi oleh Entamoeba spp. dengan prevalensi 52\%. Demikian pula pada kasus amoebiasis pada peternakan babi yang terletak di daerah pedesaan Chungcheongnam-do, Korea yang hanya dilaporkan sebanyak 3,7\% (Ismail et al., 2010).

Perbedaan hasil tersebut diduga karena letak geografis, sanitasi kandang dan sistem pemeliharaan babi pada masing-masing peternakan berbeda. Atabati et al. (2020) menyatakan bahwa faktor tempat dan cara pemeliharaan yang berbeda pada suatu peternakan berimplikasi terhadap tingkat prevalensi infeksi Entamoeba sp., di samping itu, faktor lingkungan (kontaminasi tinja di lingkungan), standar kebersihan dan sanitasi yang buruk berhubungan dengan infeksi parasit usus termasuk infeksi Entamoeba spp.
Babi yang dipotong di RPH Pegirian Surabaya berasal dari peternak dari berbagai daerah di Jawa Timur, antara lain Mojokerto, Probolinggo dan daerah lainnya. Pada studi ini, 63 sampel feses babi yang diambil dari Rumah Potong Hewan Pegirian Surabaya berasal dari daerah Mojokerto. Sampel positif kemungkinan berasal dari peternakan dengan sistem pemeliharaan yang kurang baik. Menurut Levine (1994), kejadian infeksi parasit terjadi akibat sistem pemeliharaan babi yang masih bersifat tradisional sehingga mudah terkena penyakit, manajemen pemeliharaan yang kurang baik dan sanitasi kandang yang buruk dapat meningkatkan risiko infeksi.

Morfologi Entamoeba spp. yang terdeteksi dalam pemeriksaan parasitologis pada studi ini berukuran berkisar antara 11,38-16,12 $\mu \mathrm{m}$ dan kebanyakan dengan inti tunggal. Morfologi tersebut menyerupai kista Entamoeba spp. (Entamoeba cyst-like). Ukuran kista mirip dengan hasil deteksi yang dilakukan oleh Clark et al. (2006), yaitu berukuran antara 9,5-15,5 $\mu \mathrm{m}$ dan memiliki inti tunggal. Karakteristik morfologi yang paling sederhana untuk digunakan dalam identifikasi spesies Entamoeba adalah jumlah nukleus per kista, setiap spesies menghasilkan kista dengan jumlah inti yang bervariasi, yaitu satu, empat atau delapan inti dan bahkan beberapa tidak memiliki inti. Namun demikian, sejauh ini deskripsi morfologi sering tidak lengkap dan tidak jelas sehingga, menyebabkan keraguan untuk validasi dalam menentukan perbandingan masing-masing spesies sehingga hampir mustahil dilakukan dalam beberapa kasus. Pernyataan ini sesuai dengan pendapat Clark et al. (2006) yang menyatakan bahwa ukuran kista, jumlah inti kista dan tampilan bar kromatoidal (array kristal ribosom) menjadi kriteria utama dalam upaya identifikasi spesies Entamoeba.

Uji molekuler menjadi alternatif yang dipercaya mampu membantu dalam tahap identifikasi $E$. suis. Dari 36 sampel positif secara pemeriksaan parasitologis dipilih enam sampel secara acak untuk dilanjutkan ke tahap analisis molekuler. Hasil PCR membuktikan bahwa semua sampel tersebut menunjukkan pita DNA dengan ukuran 320 bp yang mengindikasikan sebagai $E$. suis. Walaupun tidak semua sampel dianalisis secara molekuler, namun hasil ini cukup representatif dalam menggambarkan hasil pemeriksaan feses secara parasitologis (Gambar 1).

Studi molekular E. suis di Indonesia masih 


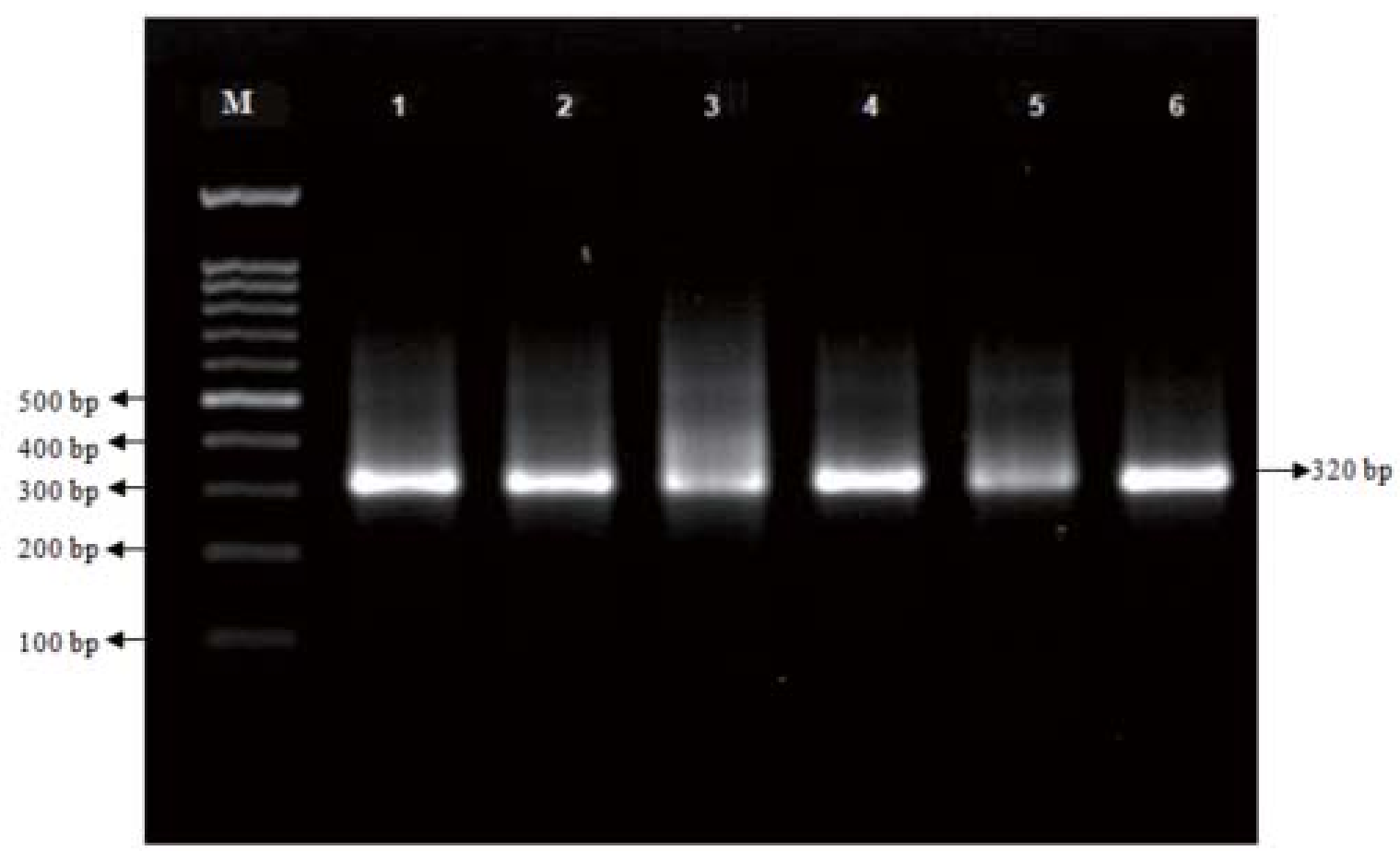

Gambar 1. Hasil visualisasi produk PCR Entamoeba suis pada gel agarose 1,5\%, tampak pita DNA pada posisi 320 bp. M: Marker DNA, 1-6: sampel yang diperiksa.

sangat terbatas. Oleh karena itu, konfirmasi spesies protozoa gastrointentinalis yang menginfeksi peternakan babi menjadi sangat penting. Salah satu studi terbaru tentang Entamoeba spp. pada babi secara molekuler dilaporkan oleh Wardhana et al. (2020). Kasus infeksi $E$. suis pada peternakan babi di Tangerang, Jawa Barat dilaporkan mencapai $81,1 \%$. Studi tersebut juga mengidentifikasi $E$. polecki hingga ke arah sub type genetik. Hasil sekuensing DNA pada sampel-sampel tersebut tidak menunjukkan keragaman genetik $E$. suis yang menginfeksi babi di Tangerang. Namun, studi tersebut memberikan informasi terjadinya infeksi campuran antara $E$. suis dan $E$. polecki yang menyerang sejumlah babi di peternakan tersebut, beberapa di antaranya masuk kedalam kelompok sub type yang bersifat zoonosis.

Hasil studi ini menunjukkan prevalensi yang lebih tinggi dari studi yang dilaporkan di Cina $(0,8 \% ; 4 / 500)$ (Li et al., 2018) dan di Iran $(9 \% ; 2 / 12)$ (Solaymani-Mohammadi et al., 2004). Li et al. (2018) melaporkan prevalensi yang berbeda dapat disebabkan oleh ukuran sampel, prosedur deteksi, variasi geografis, usia inang, jenis kelamin, status kesehatan dan waktu pengambilan spesimen.

Berdasarkan analisis molekuler membuk- tikan bahwa dugaan $E$. suis sebagai spesies yang paling banyak menginfeksi ternak babi dan tersebar di seluruh dunia menjadi relevan. Semula para peneliti berkeyakinan bahwa spesies ini bersifat tidak patogen. Namun, pendapat tersebut terbantahkan melalui kasus amoebiasis yang menyebabkan kematian babi di beberapa peternakan di Jepang. Matsubayashi et al. (2014, 2015a, 2015b) berhasil mengidentifikasi E. suis dan E. polecki sebagai penyebab utama kematian babi pada tiga peternakan babi komersial di Jepang. Entamoeba suis dilaporkan menyebabkan kolitis hemoragik sebagai akibat invasi pada lamina propria (Matsubayashi et al., 2014).

Status patogenisitas E. suis belum diketahui apakah bergantung pada tingkat keparahan infeksi, adanya infeksi campuran dengan patogen lain atau status kesehatan inang. Hasil penelitian Matsubayashi et al. (2015a) menunjukkan adanya koinfeksi Entamoeba spp. dengan Lawsonia intracellularis sehingga meningkatkan keparahan penyakit amoebiasis. Analisis lebih lanjut terkait koinfeksi bakteri dengan protozoa pada peternakan babi di Indonesia dapat menjadi pertimbangan dalam menentukan strategi manajemen pemeliharaan babi untuk 
menurunkan prevalensi atau mortalitas akibat penyakit ini.

\section{SIMPULAN}

Beberapa babi yang dipotong di Rumah Potong Hewan Pegirian Surabaya terinfeksi Entamoeba spp. (57,14\%) berdasarkan pemeriksaan parasitologis pada feses. Adapun identifikasi spesies secara molekular pada beberapa sampel positif tersebut terkonfirmasi sebagai E. suis.

\section{SARAN}

Penelitian ini dapat dilanjutkan ketahap sekuensing DNA untuk mengetahui perubahan susunan nukleotida dan homologi $E$. suis dari isolat lokal dengan isolat yang telah terdaftar di Gen Bank, di samping itu, studi molekuler dapat dilakukan dengan primer spesifik spesies Entamoeba yang lain sehingga dapat mendeteksi kemungkinan terjadinya infeksi campuran sebagai penyebab diare pada ternak babi.

\section{UCAPAN TERIMA KASIH}

Penulis mengucapkan terima kasih dan penghargaan yang setinggi-tingginya kepada Prof Makoto Matsubayashi DVM, PhD dari Osaka Prefecture University atas hibah primer Entamoeba. Ucapan terima kasih juga penulis sampaikan kepada Fakultas Kedokteran Hewan Universitas Airlangga atas fasilitas penelitian dan kesempatan mengikuti pendidikan Magister pada Program Studi S2 Ilmu Penyakit dan Kesehatan Masyarakat Veteriner.

\section{DAFTAR PUSTAKA}

Agustina KK, Dharmayudha AAGO, Oka IBM, Dwinata IM, Kardena IM, Dharmawan NS, Damriyasa IM. 2016. Case of Entamoebiasis in pigs Raised with a Free Range systems in Bali, Indonesia. Udayana Jurnal Veteriner 17(4): 570-575.

Atabati H, Kassiri H, Shamloo E, Akbari M, Atamaleki A, Sahlabadi F, Linh NTT, Rostami A, Fakri Y, Khaneghah AM. 2020. The association between the lack of safe drinking water and sanitation facilities with intestinal Entamoeba spp infection risk: A systematic review and metaanalysis. PLoS ONE 15(11): e0237102. https://doi.org/ 10.1371/journal.pone.0237102.

Clark CG, Kaffashian F, Tawari B, Windsor JJ, Twigg-Flesner A, Davies-Morel MC, Blessmann J, Ebert F, Peschel B, Le Van A, Jackson CJ, Macfarlane L, Tannich E. 2006. New insights into the phylogeny of Entamoeba species provided by analysis of four new small-subunit rRNA genes. Int $J$ Syst Evol Microbiol 56: 2235-2239.

Damriyasa IM, Bauer C. 2006. Prevalence and age-dependent occurrence of intestinal protozoan infections in suckling piglets. $J$ of Berliner und Munchener Tierarztliche Wochenschrift 119(7-8): 287-290.

Ismail AHHA, Jeon H, Yu Y, Do C, Lee Y. 2010. Intestinal Parasite Infections in Pigs and Beef Cattle in Rural Areas of Chungcheongnam-do, Korea. Korean J Parasitol 48(4): 347-349.

Kagira JM, Githigia SM, Ng'ang'a JC, Kanyari PWN, Maingi N, Gachohi JM. 2010. Prevalence of gastrointestinal protozoa and association with risk factors in free-range pigs in Kenya. J Parsitol 20: 1-9.

Levine ND. 1994. Parasitologi Veteriner. Yogyakarta: UGM University Press.

Li WC, Geng JZ, Chen C, Qian L, Zhang T, Liu JL, Luo JX, Gu YF. 2018. First report on the occurance of intestinal Entamoeba spp. in pigs in China. Acta Trop 185: 385-390. https://doi.org/10.1016/j.actatropica. 2018.06.020.

Matsubayashi M, Kanamori K, Sadahiro M, Tokoro M, Abe N, Haritani M, Shibahara T. 2015a. First molecular identification of Entamoeba polecki in a piglet in Japan and implications for aggravation of ileitis by coinfection with Lawsonia intracellularis. Parasitol Res 114: 3069-3073.

Matsubayashi M, Murakoshi N, Komatsu T, Tokoro M, Haritani M, Shibahara T. 2015b. Genetic identification of Entamoeba polecki subtype 3 from pigs in Japan and characterisation of its pathogenic role in ulcerative colitis. Infect Genet Evol 36: 814

Matsubayashi M, Suzuta F, Terayama Y, 
Shimojo K, Yui T, Haritani M. Shibahara T. 2014. Ultrastructural characteristics and molecular identification of Entamoeba suis isolated from pigs with hemorrhagic colitis: implications for pathogenicity. Parasitol Res 113: 3023-3028.

Matsubayashi M, Sasagawa Y, Aita T, Tokoro M, Haritani M, Shibahara T. 2016. First report ofmixed Entamoeba polecki (ST 1) and $E$. suis infection in piglets shedding abnormal feces by histopathological and molecular surveys. Acta Parasitol 61: 665670.

Meyer A, Todt C, Mikkelsen NT, Lieb B. 2010. Fast evolving 18S rRNA sequences from Solenogastres (Mollusca) resist standard PCR amplification and give new insights into mollusk substitution rate heterogeneity. BMC Evolutionary Biology 10: 10-70.

Mohamadi SS, Petri WA. 2006. Zoonotic Implications of The Swine-Transmitted Protozoal Infections. Veterinary Parasitology 140(2006): 189-203.

Perwakot. 2010. Susunan Organisasi dan Tata Kerja Perusahaan Daerah Rumah Potong Hewan Kota Surabaya. Surabaya. Peraturan Walikota Surabaya No. 31 Tahun 2010 Hlm. 4.

Solaymani-Mohammadi S, Rezaian M, Hooshyar H, Mowlavi GR, Babaei Z, Anwar MA. 2004. Intestinal protozoa in wild boars (Sus scrofa) in western Iran. J Wildl Dis 40: 801-803.

Sukprasert S, Rattaprasert P, Hamzah Z, Shipin OV, Chavalitshewinkoon-Petmitr P. 2008. PCR detection of Entamoeba spp from surface and waste water samples using genus-specific primers. Southeast Asia $J$ Trop Med Public Health 39(1): 6-9.

Suryawan GY, Suratma NA, Damriyasa IM.
2014. Potential at pig source of transmission zoonotic diseases Entamoeba spp. Bul Vet Udayana 6(2): 141-145.

Suwanti LT, Lastuti NDR, Mufasirin, Suprihati E. 2011. Petunjuk dan Laporan Praktikum Ilmu Penyakit Protozoa. Surabaya. Departemen Parasitologi Veteriner. Fakultas Kedokteran Hewan Universitas Airlangga.

Verweij JJ, Polderman AM, Clark CG. 2001. Genetic Variation among Human Isolates of Uninucleated Cyst-Producing Entamoeba Species. J Clin Microbiol 39(4): 1644-1646.

Verweij JJ, Laeijendecker D, Brienen EA, van Lieshout L, Polderman AM. 2003. Detection and identification of Entamoeba species in stool samples by a reverse line hybridization assay. J Clin Microbiol 41: 5041-5045.

Wardhana AH, Sawitri DH, Ekawasti F, Martindah E, Apritadewi D, Shibahara T, Kusumoto M, Tokoro M, Sasai K, Matsubayashi M. 2020. Occurrence and genetic identifications of porcine Entamoeba, $E$. suis and E. polecki, at Tangerang in West Java, Indonesia. https://doi.org/10.1007/ s00436-020-06806-0.

Widisuputri NK, Suwanti LT, Plumeriastuti H. 2020. A Survey for Zoonotic and Other Gastrointestinal Parasites in Pig In Bali Province, Indonesia. Indonesian Journal of Tropical and Infectious Disease. 8(1). https:/ /ejournal.unair.ac.id/IJTID/article/view/ 10393.

Yuliari PK, Damriyasa IM, Dwinata IM. 2013. Prevalensi Protozoa pada Babi di Lembah Baliem dan Pegunungan Arfak Papua. Indonesia Medicus Veterinus 2(2): 208-215. 